\title{
Chromoblastomycosis: an etiological, epidemiological, clinical, diagnostic, and treatment update*
}

\author{
Arival Cardoso de Brito ${ }^{1,2,3}$, Maraya de Jesus Semblano Bittencourt ${ }^{1}$
}

DOI: http:/ /dx.doi.org/10.1590/abd1806-4841.20187321

\begin{abstract}
Chromoblastomycosis is a chronic, granulomatous, suppurative mycosis of the skin and subcutaneous tissue caused by traumatic inoculation of dematiaceous fungi of the family Herpotrichiellaceae. The species Fonsecaea pedrosoi and Cladophialophora carrionii are prevalent in regions where the disease is endemic. Chromoblastomycosis lesions are polymorphous: verrucous, nodular, tumoral, plaque-like, and atrophic. It is an occupational disease that predominates in tropical and subtropical regions, but there have been several reports of cases in temperate regions. The disease mainly affects current or former farm workers, mostly males, and often leaving disabling sequelae. This mycosis is still a therapeutic challenge due to frequent recurrence of lesions. Patients with extensive lesions require a combination of pharmacological and physical therapies. The article provides an update of epidemiological, clinical, diagnostic, and therapeutic features.
\end{abstract}

Keywords: Chromoblastomycosis; Diagnosis; Diagnostic tests, routine; Epidemiology; Fungi; Therapeutics; Treatment outcome

\section{INTRODUCTION}

Chromoblastomycosis (CBM) is a chronic, granulomatous mycosis of the skin and subcutaneous tissue produced by the traumatic inoculation of various dematiaceous fungi of the order Chaetothyriales and family Herpotrichiellaceae, present in soil, plants, and decomposing wood, prevalent in tropical and subtropical regions of the world. ${ }^{1,2} \mathrm{CBM}$ is a progressive, disabling, difficult-to-treat occupational disease, evolving with episodes of secondary bacterial infections, leading to low work productivity and frequent absenteeism. The synonyms for this mycosis vary widely, including: chromomycosis, verrucous dermatitis, Lane-Pedroso's mycosis, Fonseca's disease, Carrión's mycosis, cladosporiosis, figueira, formigueiro, blastomycosis nigra, sunda, susna, and chapa, among others.

\section{HISTORY}

In 1922, Terra et al. coined the term chromoblastomycosis to refer to the disease. ${ }^{3}$ Seventy years later, in 1992, the term was proposed by the International Society for Human and Animal Mycology (ISHAM) as the official name for the mycosis from that publication forward. ${ }^{4}$ McGinnis, in 1983, finalized the long controversy over the nomenclature for the mycosis with the publication in which he clearly established the concept of chromoblastomycosis, differentiating it from phaeohyphomycosis and other infections caused by fungi of the family Herpotrichiellaceae (order Chaetothyriales). ${ }^{1}$ CBM is currently classified by the International Classification of Diseases as follows: ICD-9 117.2 and ICD 10-B43. ${ }^{5}$

Received 08 June 2017.

Accepted 24 September 2017.

* Work conducted at the Dermatology Service, Universidade Federal do Pará, Belém (PA), Brazil.

Financial support: None.

Conflict of interest: None.

Dermatology Course, Universidade Federal do Pará, Belém (PA), Brazil.

Medical Residency in Dermatology, Universidade Federal do Pará, Belém (PA), Brazil.

Dermatopathology Laboratory, Universidade Federal do Pará, Belém (PA), Brazil.

CORRESPONDING AUTHOR:

Maraya de Jesus Semblano Bittencourt

E-mail: marayabittencourt@hotmail.com

(C)2018 by Anais Brasileiros de Dermatologia 
The first cases of CBM were observed by Pedroso and Gomes in 1911, but it was not until 1920 that the authors published the four cases which they reported as having been caused by Phialophora verrucosa. ${ }^{6}$ However, Brumpt ${ }^{7}$ contended that the fungus belonged to a different species, which he named Hormodendrum pedrosoi, later renamed Fonsecaea pedrosoi by Negroni. ${ }^{8}$ According to Castro and Castro", the first author to publish was a German physician Max Rudolph $^{10}$, who lived in Brazil, and who in 1914 published six cases of CBM observed in the town of Estrela do Sul, Minas Gerais State. Rudolph emphasized the disease's clinical characteristics, and in four of the six cases he cultured and isolated a brownish-black fungus which he inoculated in animals. There is no record of a histopathology report. In 1915, Medlar ${ }^{11}$ and Lane ${ }^{12}$ described the first cases of CBM in the United States. Thaxter isolated and classified the fungus from these cases, calling it Phialophora verrucosa.

In 1928, Hoffman reported ten cases of a disease similar to CBM observed by Guiteras in Cuba in 1908, but not published. ${ }^{13}$ The first case outside of the Americas was described by Montpellier and Catanei in 1927 in an Algerian patient. ${ }^{14}$ The second case in the United States was reported by Wilson et al. in $1933 .{ }^{15}$ In 1935, as the name "chromoblastomycosis" suggested that the etiological agents display budding yeasts in the tissue, Moore and Almeida (1935) proposed the term "chromomycosis" to replace "chromoblastomycosis". ${ }^{16}$ More cases were reported in European countries. ${ }^{17}$ The fungus Acrotheca aquaspersa, later Rhinocladiella aquaspersa, was described in 1972 by Borelli. $^{18}$

The World Health Organization (WHO) keeps a long list of neglected diseases, which is defined as endemic tropical and subtropical diseases in low-income populations that cause thousands of deaths a year. The list includes diseases caused by infectious and parasitic agents (fungi, viruses, bacteria, protozoans, and helminths). In Brazil, the neglected diseases include deep mycoses such as $\mathrm{CMB}$, paracoccidioidomycosis, Jorge Lobo's disease, mycetomas, sporotrichosis, and others.

\section{ETIOLOGY}

The etiological agents of CBM belong to the order Chaetothyriales, family Herpotrichiellaceae, and include: Fonsecaea pedrosoi, Fonsecaea monophora, Cladophialophora carrionii, Fonsecaea nubica, Phialophora verrucosa, Fonsecaea pugnacius, Rhinocladiella aquaspersa, Cladophialophora samoensis, Cyphellophora ludoviensis, Rhinocladiella tropicalis, and Rhinocladiella similis. ${ }^{1,5,11,12,18-25}$ Studies on the ribosomal DNA (rDNA) internal transcribed spacer showed that Fonsecaea pedrosoi and Fonsecaea compacta are identical species. ${ }^{26}$

The most prevalent species $(90 \%)$ is F. pedrosoi. ${ }^{19,20,27-30}$ Cases of CBM caused by Exophiala jeanselmei and Exophiala spinifera have been reported in the literature. ${ }^{31-34}$ In Panama (2007), there is a report of CBM caused by Chaetomium funicola. ${ }^{35}$

In the tissues, the fungi display a micromorphology of round/oval, brownish, thick-walled cells 4-12 microns in diameter, which multiply by septation in two distinct planes, called muriform (sclerotic) bodies (cells) or Medlar's bodies, representing the invasive form. The term muriform is preferred to sclerotic, according to Matsumoto. ${ }^{36}$ The melanin from the dematiaceous fungi is formed by the polymer dihydroxy naphthalene (DHN), which forms the melanin complex by interacting with proteins, lipids, and carbohydrates from the cell wall and represents an important factor in the virulence of these fungi. ${ }^{37}$

\section{EPIDEMIOLOGY}

CBM is a cosmopolitan disease, with the highest prevalence in tropical and subtropical regions between $30^{\circ}$ latitude North and $30^{\circ}$ latitude South. ${ }^{38}$ The largest focus of CBM in the world is in Madagascar, Africa. ${ }^{39}$ However, the mycosis displays variable incidence in South America, Central America, North America, Asia, and Europe. Among the countries with temperate climates, there have been reports in Russia, Canada, Finland, Czech Republic, Romania, and Poland, in addition to high incidence in Japan. . $^{17,40-45}$

In Venezuela, C. carrionii predominates in the arid states of Lara and Falcón, while F. pedrosoi predominates in humid areas. ${ }^{20,23,27,28,46}$ The mycosis occurs in most states of Brazil, the country with the second largest case series, and where the state of Pará has the highest prevalence. ${ }^{23,28,30,47,48}$ Current or former agricultural workers, miners, and woodsmen, predominantly males 20 to 60 years of age, account for $90 \%$ of the cases. There is no ethnic predilection. In Japan, the lesions predominate on the upper limbs, face, and neck. ${ }^{44,45}$ There is no record of direct human-to-human or animal-to-human transmission. ${ }^{20}$

\section{PATHOGENESIS}

The etiological agents of this mycosis, generally with low pathogenic power, live as saprophytes in the soil, plants, and organic matter in decomposition. Connant in 1937 demonstrated for the first time that the agents of CBM exist in nature, by isolating fungus Cadophora Americana (later renamed P. verrucosa) from wood. ${ }^{49}$ Various subsequent studies confirmed the etiological agents' presence in the environment. ${ }^{50-54} \mathrm{CBM}$ results from the transcutaneous, traumatic inoculation of propagules from various species of dematiaceous fungi. In the host, the propagules adapt to the tissue environment through the dimorphism of the filamentous phase in globe-shaped structures called muriform cells.

The immune response in CBM is not totally clear, although the main response is cellular, involving macrophages, Langerhans cells, factor XIIIa+ dermal dendrocytes, in addition to the humoral response. In 2003, D'Ávila et al. analyzed CBM-spectrum disease, relating the clinical forms to the cytokine profile. ${ }^{55}$ Verrucous lesions presented parasite-rich granulomas and predominance of IL4 and IL10, a Th2 response. In the atrophic forms, they observed well-formed granulomas with more epithelioid and Langhans cells, IFN-gamma, and TNF-alpha, a Th1 response profile.

Souza et al. (2008) observed that the monocytes of patients with a severe form of the disease showed increased production of IL-10 and lower expression of HLA-DR and costimulatory molecules. ${ }^{56}$ According to the authors, immune modulation with recombinant IL-12 or anti-IL10 can restore the Th1 immune response in these patients. ${ }^{56}$

Some studies have addressed macrophage activation and destruction of F. pedrosoi, but there is also in vitro evidence that the fungus can reduce the efficacy of macrophages, with inhibition of the immune response and fungal persistence in the tissues. ${ }^{57-59}$ 
Sotto et al. investigated the cellular immune response, especially antigen distribution in patients' biopsy specimens. ${ }^{60} \mathrm{In}$ their study, the majority of antigens were observed in the cytoplasm of the macrophages, and to a lesser extent in the Langerhans cells and factor XIIIa- positive dendrocytes. ${ }^{60}$

Gimenes et al. demonstrated that patients with the severe form of CBM produce high levels of IL-10 and low levels of IFN- $\gamma$, together with inefficient T-cell proliferation. ${ }^{61}$ Meanwhile, patients with the mild form show intense production of IFN- $\gamma$, low levels of IL-10, and efficient T-cell proliferation. The interaction of conidia or sclerotic F. pedrosoi cells with Langerhans cells with decreased expression of CD40 and B7-2 and immune function inhibition was demonstrated by Silva et al. ${ }^{62}$ The immunohistochemical analysis of 23 biopsies from the untreated verrucous form of CBM evidenced local immune response with high IL-17 expression and low expression of other cytokines, but this Treg/Th17 imbalance can provide proof of decreased immune response to the fungus. ${ }^{63}$

Siqueira et al. showed that the hyphae and muriform cells are capable of establishing murine CBM with skin lesions and similar histopathological features to those found in human tissue, and that the muriform cells are the most persistent fungal form, while the mice infected with conidia do not reach the chronic phase of the disease ${ }^{64}$ They further demonstrated that in the damaged tissue, the presence of hyphae and especially of muriform cells, but not of conidia, correlates with the intense production of proinflammatory cytokines in vivo. The analysis of high throughput RNA sequencing showed strong regulation of genes related to fungal recognition, cell migration, inflammation, apoptosis, and phagocytosis in macrophages exposed in vitro to muriform cells, but not to conidia. They also demonstrated that only the muriform cells needed recognition of $F_{c \gamma} R$ and dectin- 1 for in vitro internalization and that this is the principal fungal form responsible for the intense inflammatory pattern observed in CBM, thereby elucidating the chronic inflammatory reaction seen in the majority of patients. ${ }^{64}$

\section{CLINICAL MANIFESTATIONS}

CBM manifests clinically as oligosymptomatic or asymptomatic lesions, which would explain why patients only tend to seek medical care after months or even years of living with the disease.

\section{Chart 1: Clinical classification of chromoblastomycosis types} according to Carrión (1950)

\begin{tabular}{ll} 
Nodular & $\begin{array}{l}\text { Fibrotic, erythematous-violaceous no- } \\
\text { dules, with smooth or hyperkeratotic } \\
\text { surface }\end{array}$ \\
Verrucous or warty & $\begin{array}{l}\text { Cauliflower-like, dry, hyperkeratotic le- } \\
\text { sions with black dots }\end{array}$ \\
$\begin{array}{l}\text { Plaque (infiltrative } \\
\text { or erythematous) }\end{array}$ & $\begin{array}{l}\text { Erythematous or violaceous plaques, in- } \\
\text { filtrated, circumscribed, irregular, sharp } \\
\text { and elevated edges, with black dots }\end{array}$ \\
Tumoral & $\begin{array}{l}\text { Isolated or coalescent lobulated lesions, } \\
\text { smooth or vegetative-like surface }\end{array}$ \\
Cicatricial or atrophic & $\begin{array}{l}\text { Annular, serpiginous, or irregular le- } \\
\text { sions with centrifugal growth and cen- } \\
\text { tral atrophic areas }\end{array}$ \\
\hline
\end{tabular}

The initial lesion is usually on exposed areas, at the infection site, as a papule with centrifugal growth that evolves to any one of the several clinical forms. The polymorphism of CBM lesions encouraged some authors to develop various classifications of the clinical forms, most of which no longer used, while the classification proposed by Carrión in 1950 (Chart 1) is still in use. ${ }^{65}$

The initial lesion may remain circumscribed to the inoculation site for months or years, but it usually evolves to one of the lesion types characterizing the clinical polymorphism of CBM (Figure 1). By contiguity or lymphatic or hematogenous dissemination, metastatic lesions appear at other anatomic sites. In the nodular type, the clinical expression is that of fibrotic, erythematous-violaceous nodules with a smooth or hyperkeratotic surface (Figure 2). The verrucous type - with a higher prevalence, is characterized by lesions with a cauliflower appearance, dry, hyperkeratotic, with black dots, usually with abundant CBM agents, but ulceration occurs relatively frequently in this type of lesion (Figure 3). The plaque type displays erythematous or violaceous, infiltrated, circumscribed, irregular plaques, with sharp, elevated edges and black dots, in some cases with central scarring (Figure 4). The tumoral type is characterized by lobulated single or coalescent tumoral lesions with a smooth or crusted/scaly surface, or a vegetative appearance (Figure 5). In the cicatricial or atrophic type, the clinical appearance involves lesions with an annular, serpiginous, or irregular configuration and centri-

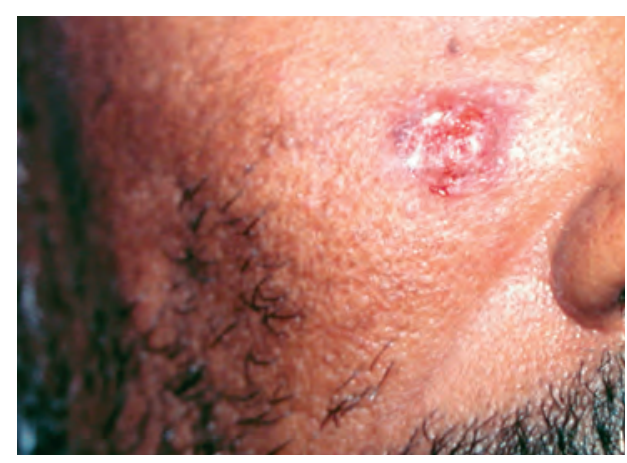

Figure 1: Types of CBM lesions according to Carrión (1950). Initial CBM lesion

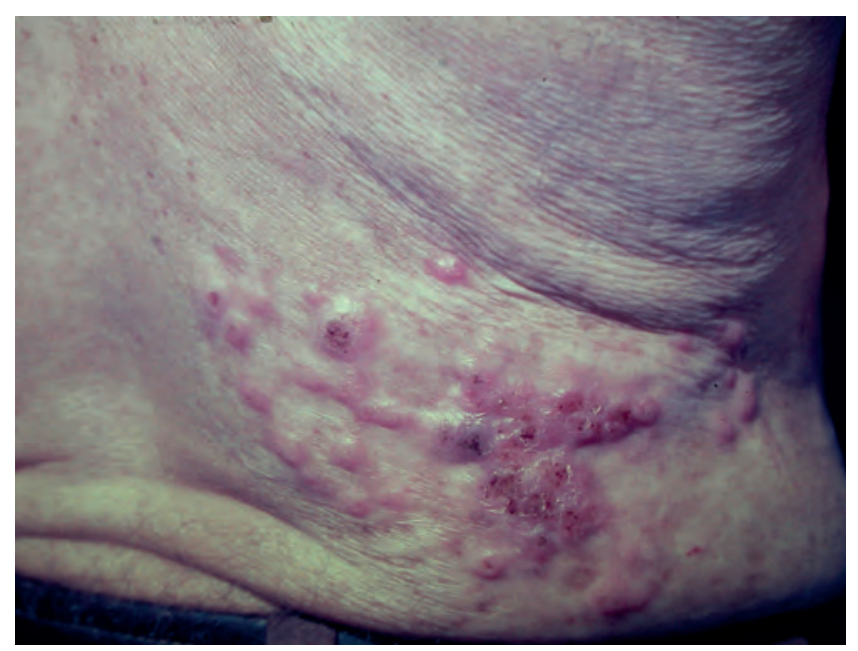

Figure 2: Types of CBM lesions according to Carrión (1950). Nodular 


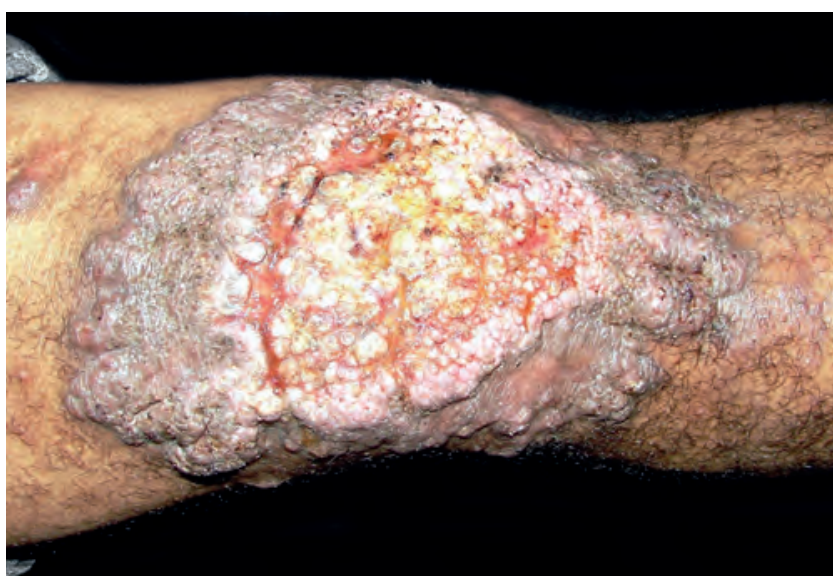

Figure 3: Types of CBM lesions according to Carrión (1950). Verrucous

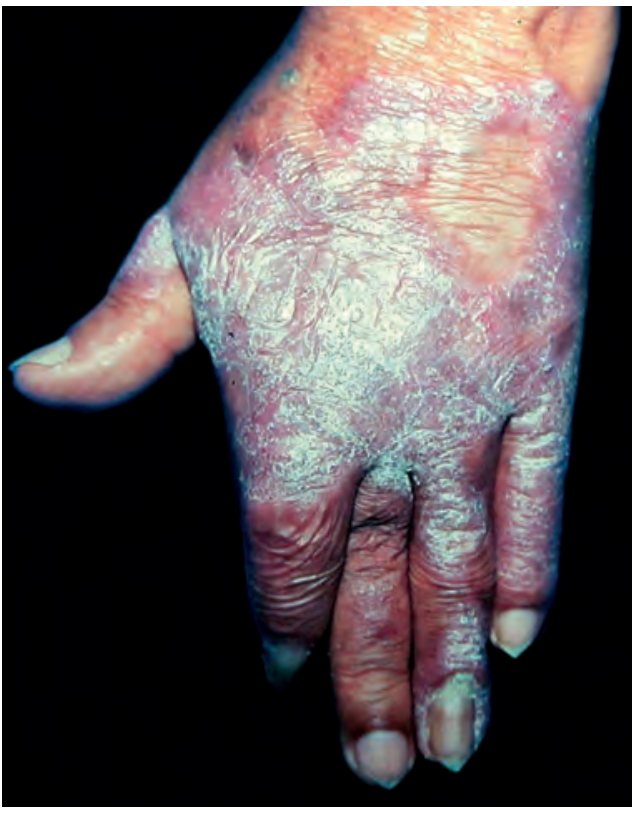

Figure 4:

Types of CBM lesions according to Carrión (1950). Plaque

fugal growth with atrophic central areas, in some cases occupying large skin areas (Figure 6).

The great majority of CBM lesions are located on the lower limbs, especially in agricultural workers. Reports in the literature of different clinical features and other sites include: localized annular form, diffuse cutaneous form, on the scapular region, two cases on the axillae, on the abdomen, on the cornea, on the conjunctiva simulating melanoma, on the auricular region, and as a phagedenic ulcer on the face. ${ }^{43,66-76}$

Oral CBM was reported by Fatemi et al..$^{77}$ Cases of extracutaneous CBM are rare, but hematogenous, lymphatic, or contiguous dissemination of the fungus has been known to metastasize to lymph nodes and lungs and produce osteolytic lesions underlying the skin lesion. ${ }^{78-80}$ There are reports of fatal cases of brain abscesses caused by F. monophora and F. pugnacius. ${ }^{22}$

Although most CBM patients are adults, cases of the mycosis have been reported in children and adolescents in endemic re-

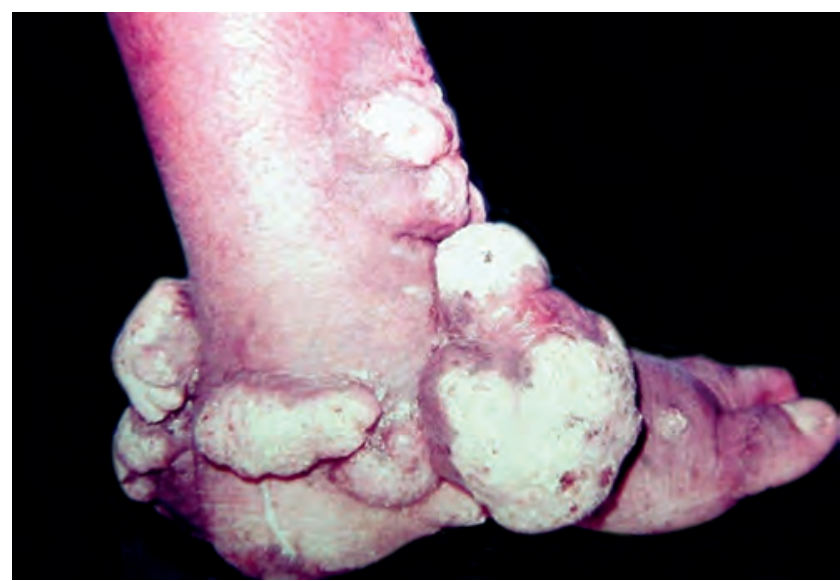

Figure 5: Types of CBM lesions according to Carrión (1950). Tumoral

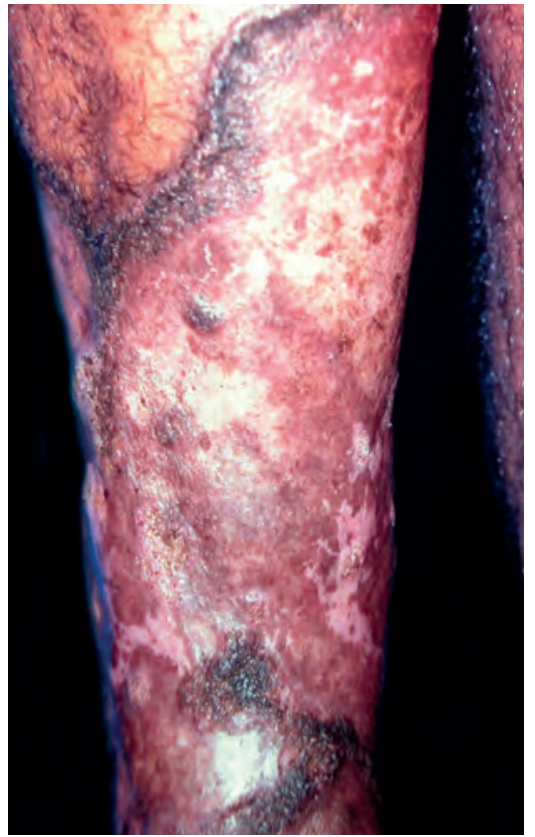

Figure 6: Types of CBM lesions according to Carrión (1950). Cicatricial

gions. ${ }^{27}$ The clinical manifestations of CBM display different degrees of severity, as follows: ${ }^{81}$

Mild form: single lesion, plaque or nodular type, less than 5 $\mathrm{cm}$ in diameter (Figure 7A).

Moderate form: single or multiple lesions, plaque, nodular, or verrucous (verruciform). When multiple, presence of one or various types of lesions located on one or two adjacent skin areas, less than $15 \mathrm{~cm}$ in diameter (Figure $7 \mathrm{~B}$ ).

Severe form: any type of single or multiple lesion, adjacent or otherwise, covering extensive areas of the skin. When multiple, combined presence of one or several types of lesions (Figure 7C).

Patients report pruritis of variable intensity in the lesions, and pain in the presence of secondary infection. The following complications occur in CBM: bacterial infection, elephantiasis, and carcinomatous degeneration. ${ }^{82-90}$ 

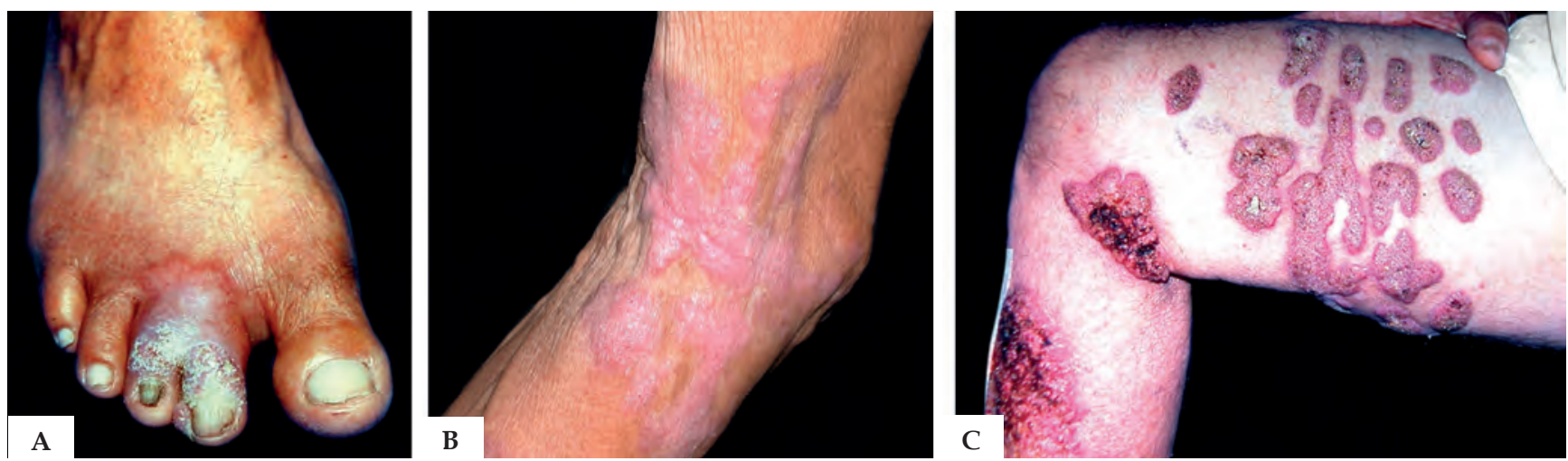

Figure 7: CBM lesions according to severity criteria. A - mild; B - moderate; C - severe

\section{DIFFERENTIAL DIAGNOSIS}

The polymorphism of CBM lesions makes differential diagnosis mandatory with pathological processes of different etiologies, including: phaeohyphomycosis, paracoccidioidomycosis, sporotrichosis, lobomycosis (lacaziosis), coccidioidomycosis, North American blastomycosis, leishmaniasis, mycetoma, leprosy, cutaneous tuberculosis, non-TB mycobacterial infections, protothecosis, rhinosporidiosis, botryomycosis, tertiary syphilis, ecthyma, sarcoidosis, psoriasis, halogenoderma, and neoplasms, including squamous cell carcinoma, keratoacanthoma, and sarcoma (Figure 8).

\section{LABORATORY DIAGNOSIS}

Direct microscopy using potassium hydroxide $(\mathrm{KOH}) 10-$ $20 \%$ or $\mathrm{KOH} / \mathrm{DMSO}$ reveals muriform (sclerotic) bodies, pathognomonic of CBM regardless of the causative species (Figure 9A). Occasional dematiaceous hyphae may be associated with the muriform bodies in the material (Figure 9B). The specimens with the highest likelihood of a positive result are those from lesions with the so-called "black dots" that are visible on the lesion's surface, representing transdermal elimination of the fungus. Miranda et al. (2005) used vinyl adhesive tape for the diagnosis of some deep mycoses, including CBM. ${ }^{91}$

Fungal culture in Sabouraud agar is used to isolate and identify species, but the causative agents usually present very similar macromorphological characteristics. F. pedrosoi produces velvety, dark-brown, olive-green, or black colonies (Figures 10A and 10B). Phialophora verrucosa produces slow-growing, velvety, moss-green, brown, or black colonies. C. carrionii displays colonies very similar to those of F. pedrosoi (Figures 10C and 10D). R. aquaspersa colonies are velvety and moss-green to black.

Microculture yields three types of fruiting or sporulation: Cladosporium type - acrogenous catenulate sporulation, elliptical spores in chains; Phialophora type - conidiophore (phialide), flower vase-shaped with spores around the phialide; Rhinocladiella type - conidiophores formed along the hyphae and oval spores on the upper extremity (acrotheca) and along the conidiophore.

No intradermal tests for the disease have been standardized. Molecular biology techniques are currently essential to com- plete the diagnostic workup, and PCR tests have been developed to identify Fonsecaea species and C. carrionii. ${ }^{21,26,92}$ In light of the immune response in CBM patients, Oberto-Perdigon et al. used ELISA in 114 sera to assess the humoral response before, during, and after treatment employing a somatic antigen (AgSPP) of C. carrionii. ${ }^{93}$ The authors concluded that the method is valuable for diagnosis and assessment of therapeutic efficacy. However, PCR and ELISA are still not available in many endemic areas.

Histopathologically, CBM is characterized by an epidermis with hyperparakeratosis, pseudoepitheliomatous hyperplasia, intracorneal microabscesses, and transdermal elimination of fungi, the latter either inside or outside the microabscesses (Figure 11A and 11B). The dermis presents dense granulomatous inflammation with different degrees of fibrosis, consisting of mononuclear cells (histiocytes, lymphocytes, and plasma cells), epithelioid cells, giant cells (Langhans and foreign body types), and polymorphonuclear cells. Fungal cells with their characteristic micromorphology - round, dark-brown, thick-walled, 4-12 microns in diameter and with multiplanar reproduction, called muriform (sclerotic) bodies - are found in intraepidermal microabscesses in multinucleated Langhans and/ or foreign body-type cells, in suppurative or tuberculoid granulomas, easily identified by hematoxylin-eosin staining (Figure 11C).

Dimorphism may be observed, and it is possible to identify hyphae and muriform bodies in material from skin lesions. ${ }^{94}$ Pires et al., in a study of 65 patients that underwent histopathological examination with HE staining, found two main types of granulomatous tissue reaction: suppurative granuloma with abundant fungal cells, mostly from verrucous lesions, and tuberculoid granuloma, with few parasites, from plaque and atrophic lesions. ${ }^{95}$

There is an interesting report of detection of CBM agents using Ziehl-Neelsen and Wade-Fite staining, a useful approach in cases that are difficult with HE staining. ${ }^{96}$ Our study used Fite-Faraco staining and showed the dimorphism of the fungus - presence of muriform bodies associated with dematiaceous septated hyphae (Figure 11D). Saxena et al. (2015) detected abundant fungi under direct microscopy following intralesional infiltration of corticosteroids in a CBM lesion. ${ }^{97}$ 

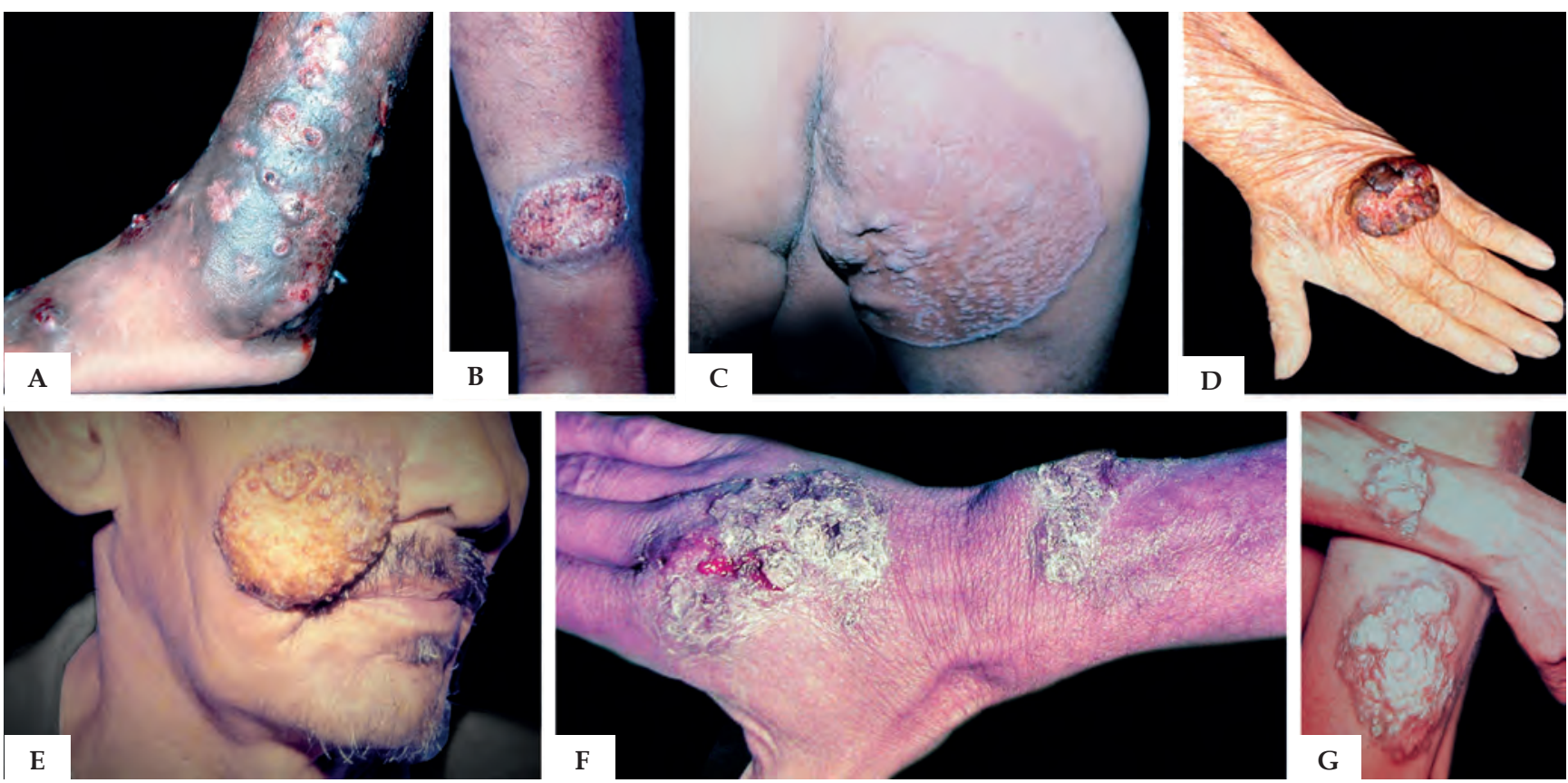

Figure 8: Differential diagnosis. A - nocardiosis; B - verrucous paracoccidioidomycosis; C - lupus vulgaris; D: squamous cell carcinoma; E - verrucous leishmaniasis; F - verrucous sporotrichosis; G - Jorge Lobo's disease
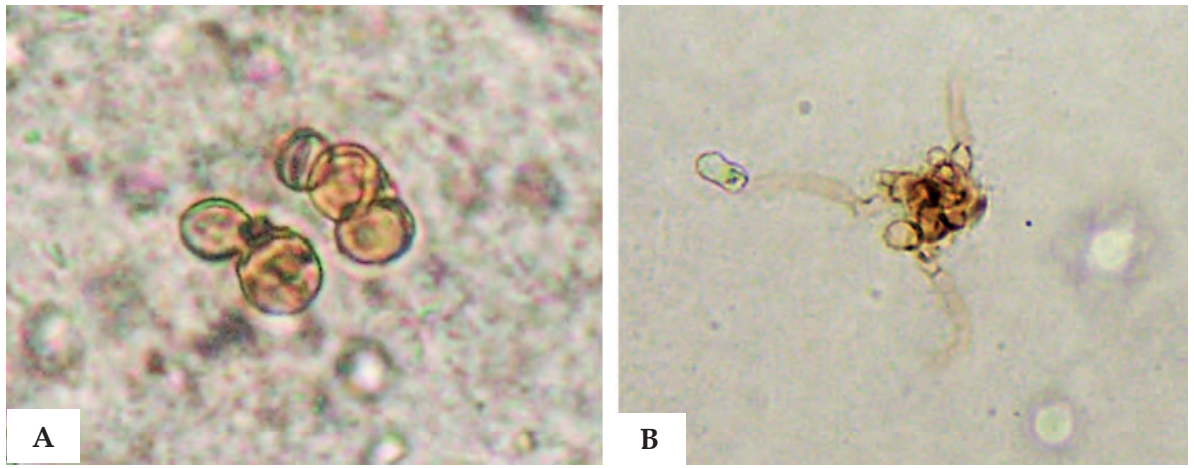

FiguRE 9: Direct mycologic examination. A - muriform bodies; B - Muriform bodies and dematiaceous hyphae

\section{TREATMENT}

CBM is difficult to treat and associated with low cure rates and high relapse rates, especially in chronic and extensive cases. Treatment choice and results depend on the etiological agent, size and extent of the lesions, topography, and presence of complications.

Clinical cure can be defined as complete resolution of all the lesions, leaving scars. Mycological cure is proven by the absence of fungi on direct mycological examination and negative culture. Histopathology of the healed lesion shows atrophic epidermis and absence of granulomatous infiltrate and abscesses, which are replaced by cicatricial fibrosis associated with chronic inflammatory infiltrate and absence of fungi in serial slices.

Treatment consists of long periods of antifungal drugs, often combined with physical treatments like surgery, cryotherapy, and thermotherapy. Studies report highly variable clinical and mycological cure rates, ranging from $15 \%$ to $80 \%{ }^{98}$

Small and localized lesions can be removed surgically with wide margins, and antifungal agents are often used before surgery to downsize the lesion and later to avoid risk of relapse. Electrodissection and curettage are not recommended, since they can result in involvement of the lymphatic chain..$^{98}$

Cryotherapy or cryosurgery with liquid nitrogen and thermotherapy (local heat to produce controlled temperatures of 42 $45^{\circ} \mathrm{C}$, which inhibit fungal growth) show minimal risk of adverse effects, and these treatment options are relatively inexpensive, but are more appropriate for single, limited lesions. ${ }^{99,100}$ Cryosurgery is relatively easy in technical terms, but the freezing time and depth have still not been standardized. Thermotherapy has been used less, and the cases with the best published results have been in Japan. The technique requires daily application of heat directly on the lesions for several hours, for 2-6 months. ${ }^{101,102}$

$\mathrm{CO}_{2}$ laser appears to be an interesting alternative for treatment of well-demarcated, localized CBM lesions. One advantage is 

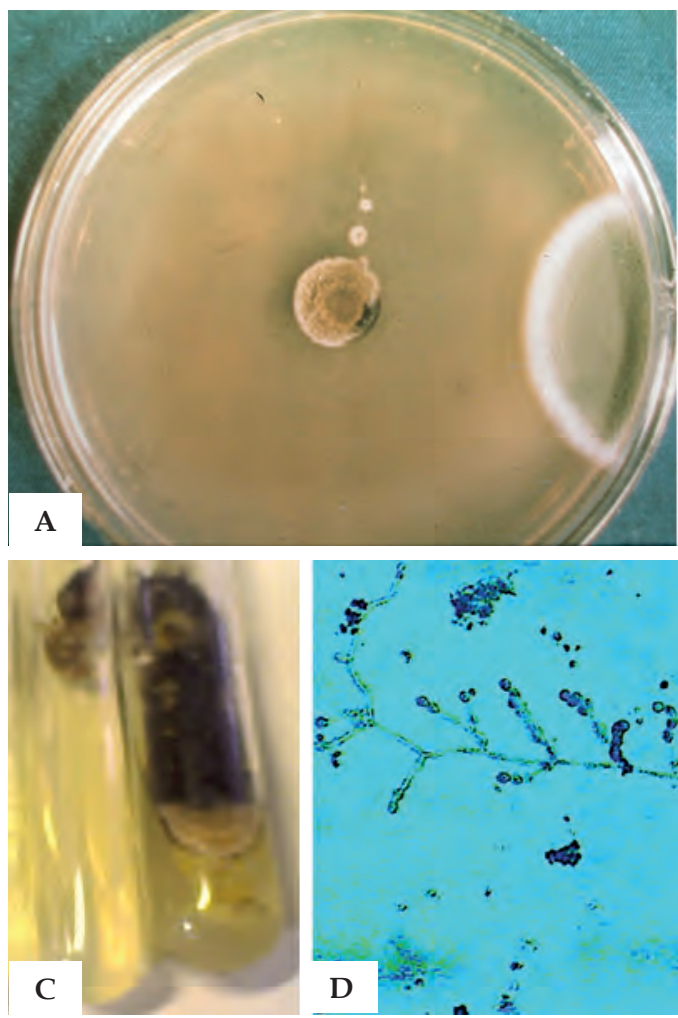
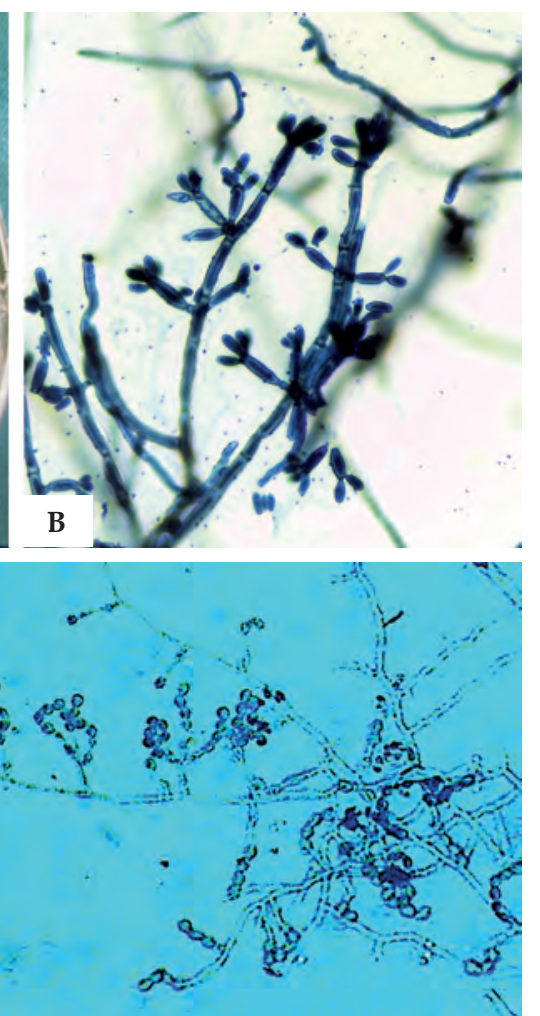

Figure 10: A - F. pedrosoi colony; B - F. pedrosoi microculture; C - C. carrionii colony; D - C. carrionii microculture the need for only a single treatment, which improves patient adherence. In addition, the cost of a single treatment is relatively low, with the advantage of no systemic toxicity. ${ }^{103}$ Combination treatment using $\mathrm{CO}_{2}$ laser and topical thermotherapy was used successfully in CBM by Hira et al. ${ }^{104}$

There was a recent promising description of photodynamic therapy in CBM. ${ }^{105,106} \mathrm{Hu}$ et al. used oral terbinafine in combination with photodynamic therapy with 5-aminolevulinic acid in a case of CBM, with apparent clinical improvement in less than a year and no recurrence. ${ }^{107}$ Mohs micrographic surgery has been used to treat a variety of skin neoplasms with excellent results. The technique was used successfully to treat a localized cutaneous CMB lesion, with no recurrence of the lesion after a year of follow-up. ${ }^{108}$

The antifungals that have shown the greatest efficacy are itraconazole (200-400mg/day) and terbinafine (500-1000mg/day) for at least 6-12 months, preferably at higher doses if tolerated..$^{109-113}$ Both drugs showed high in vitro activity against the causative agents of CBM. ${ }^{114,115}$ Pulse therapy with itraconazole was reported $(400 \mathrm{mg} /$ day for 7 days/month) and proved more economical and effective and associated with better treatment adherence. ${ }^{116,117}$ In addition, the combination of an azole (itraconazole) and an allylamine (terbinafine) with different targets and synergistic effect has been used. ${ }^{118}$

Second-generation triazoles (voriconazole, ravuconazole, posaconazole, and isavocunazole) present in vitro activity against dematiaceous fungi and are promising drugs for treatment of deep dermatomycoses, but the experience is limited by the prohibitively high costs in their endemic configuration. ${ }^{106,119-122}$

Negroni et al. ${ }^{122}$ assessed six CBM patients that were resistant to conventional antifungal therapies and administered $800 \mathrm{mg} /$ day of posaconazole, with clinical success in five of the six patients. Posaconazole was well tolerated during long-term administration. ${ }^{122}$

Oral voriconazole was tested in some cases of treatment in resistant forms of CBM. ${ }^{106,120,121}$ Good clinical results were achieved with this drug, but adverse effects like visual disturbances and photosensitive skin reactions were observed. ${ }^{121}$

Among the other antifungals, ketoconazole is not recommended for prolonged treatment, because high doses are associated with toxicity. Fluconazole is also contraindicated, since in vitro studies have shown its limited activity against dematiaceous fungi. ${ }^{115}$

Fluorocytosine (converted into 5-fluorouracil in fungal cells) shows some degree of efficacy but is associated with high risk of development of resistance, besides being hepatotoxic and myelotoxic. ${ }^{123}$ With the emergence of more recent antifungals, the drug is now rarely used except in selected resistant cases.

Amphotericin B is ineffective as monotherapy, and even in combination with other antifungals the results are generally poor, but in vivo studies of a combination of amphotericin B and fluorocytosine have shown efficacy, indicating synergistic activity between the two. ${ }^{124}$

The combination of itraconazole and fluorocytosine has only been evaluated in a small number of patients but has proven very effective even in severe forms of subcutaneous mycoses. ${ }^{125}$ The pharmacological data showed an additive effect against fungi, where fluorocytosine causes suppression of the yeast's DNA synthesis and itraconazole acts on the cell membrane, inhibiting the synthesis of ergosterol. ${ }^{126}$ Despite an insufficient number of cases for a detailed comparison, combination therapy with these two drugs can be an option in severe cases of CBM. ${ }^{126}$ 


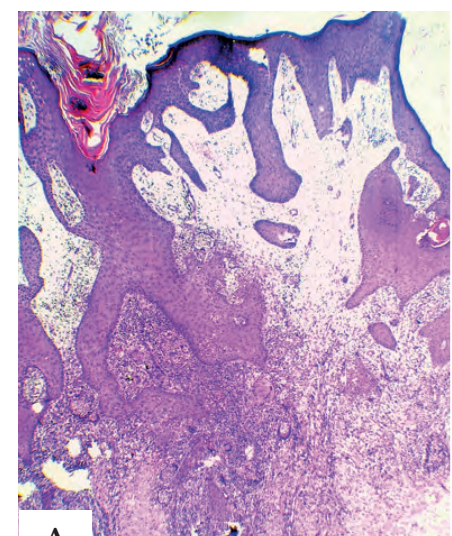

A

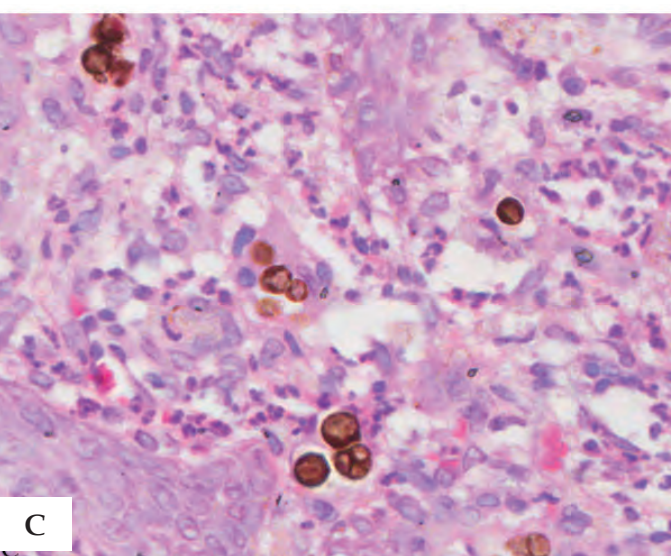

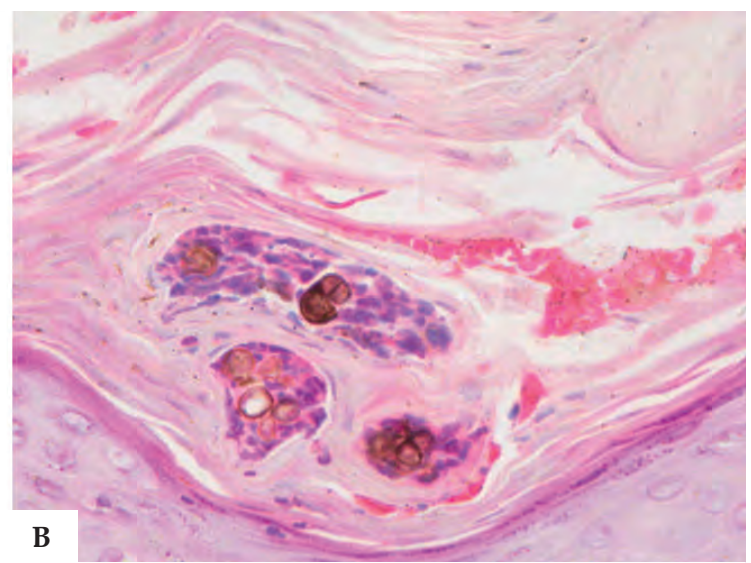

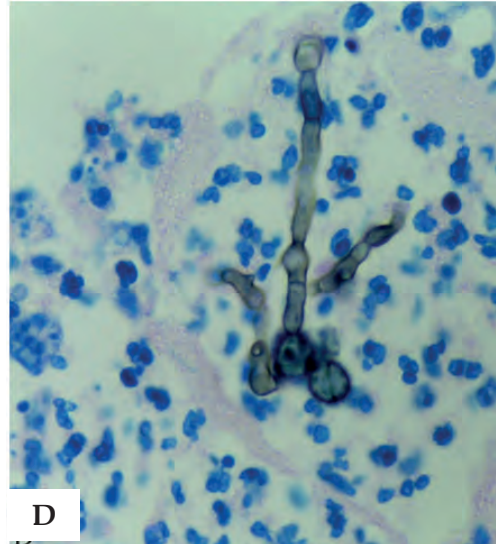

Figure 11: Histological features. A - Pseudoepitheliomatous hyperplasia, hyperparakeratosis, and dermis with edema and granulomatous inflammatory infiltrate (Hematoxylin \& eosin, x40); B - Muriform cells in the stratum corneum with transdermal elimination(Hematoxylin \& eosin, x400); C - Suppurated granuloma with muriform bodies inside giant cells (Hematoxylin \& eosin, x400); D - Muriform cells and septated hyphae in abscess (Fite-Faraco staining) x100
The combination of antifungal drugs with immunoadjuvant compounds such as glucan and imiquimod have been investigated in recent years. ${ }^{5}$ Glucan, an injectable formulation of $\beta 1 \rightarrow 3$ polyglycoside obtained from Saccharomyces cerevisiae, is considered a modifier of the biological response due to its immunomodulatory potential, since it can be recognized by specific cell receptors and has the ability to enhance the host immune response, with the activation of macrophages, endothelial and dendritic cells, B and T-cells, and polymorphonuclear lymphocytes, with the resulting induction of expression of various cytokines like TNF- $\alpha$, IL-6, IL-8, and IL-12. ${ }^{127}$ This treatment has been used successfully in some cases of leishmaniasis and paraccocidiodomycosis. ${ }^{128}$ In CBM, glucan was used in weekly subcutaneous infections combined with itraconazole, with a good clinical response. ${ }^{129,130}$ Azevedo et al. (2008) showed that after treatment with glucan, there was a significant increase in lymphoproliferation of the patient's cells in the presence of F. pedrosoi antigens, with altered cytokine pattern, showing a decrease in the production of IL-10 and a significant increase in IFN- $\gamma$ and TNF- $\alpha .{ }^{129}$
Imiquimod is a synthetic compound with potent antitumoral, immunomodulatory, and antiviral action, which stimulates both the innate and acquired immune pathways. ${ }^{131}$ Souza et al. discovered an underlying defect in the innate recognition of CBM agents by toll-like receptors (TLRs), which can be restored by exogenous administration of a TLR agonist, including imiquimod. ${ }^{132}$ Imiquimod was used in a study with topical application 4 to 5 times a week in association with oral itraconazole, with a good clinical response. ${ }^{133}$

\section{CONCLUSIONS}

CBM is an important deep cutaneous mycosis which still causes major morbidity in affected patients. It is extremely difficult to treat, especially in the more severe clinical forms. Treatment generally consists of long periods of treatment with antifungals, often associated with physical treatments and immunotherapy. New studies are being published that help elucidate the immunopathogenesis of this mycosis, aimed at developing new therapies capable of modulating the host immune response. $\square$ 


\section{REFERENCES:}

1. McGinnis MR. Chromoblastomycosis and phaeohyphomycosis: new concepts, diagnosis, and mycology. J Am Acad Dermatol. 1983;8:1-16

2. Rubin HA, Bruce S, Rosen T, McBride ME. Evidence for percutaneous inoculation as the mode of transmission for chromoblastomycosis. J Am Acad Dermatol. 1991;:25:951-4

3. Terra F, Torres M, Fonseca Filho 0. Novo tipo de dermatite verrucosa; micose por Acrotheca com associado de leishmaniose. Brasil Medico. 1922:36:363-8.

4. Odds FC, Arai T, Disalvo AF, Evans EG, Hay RJ, Randhawa HS, et al. Nomenclature of fungal diseases: a report and recommendations from a Sub-Committee of the International Society for Human and Animal Mycology (ISHAM). J Med Vet Mycol. 1992;30:1-10

5. Queiroz-Telles F, de Hoog S, Santos DW, Salgado CG, Vicente VA, Bonifaz A, et al. Chromoblastomycosis. Clin Microbiol Rev. 2017;30:233-276.

6. Pedroso A, Gomes JM. 4 casos de dermatite verrucosa produzida pela Phialophora verrucosa. Ann Paul Med Cir. 1920; 11:53-61.

7. Brumpt E. Précis de Parasitologie. 3rd ed. Paris: Masson; 1922. p.1105.

8. Negroni R. Estudio del primer caso argentino de cromomicosis, Fonsecaea (Negroni) pedrosoi (Brumpt) 1921. Rev Inst Bacteriol. 1936; 7:419-26.

9. Castro RM, Castro LG. On the priority of description of chromomycosis. Mykosen. 1987;30:397-403.

10. Rudolph MW. Über die brasilianische "Figueira". Arch Schiffs. für Tropen-Hygien 1914;18:498-9.

11. Medlar EM. A cutaneous infection caused by a new fungus Phialophora verrucosa, with a study of the fungus. J Med Res. 1915;32:507-522.9

12. Lane CG. A cutaneous disease caused by a new fungus Phialophora verrucosa. J Cutan Dis. 1915; 33:840-6.

13. Hoffman WH. Die Chromoblastomykose in Kuba. Arch SchiffsTropen-Hyg. 1928; 32:485-7

14. Montpellier J, Catanei A. Mycosehumaine due à une champignon de genre Hormodendrum, H. algeriensisn.sp. Ann. Dermatol Syphilo. 1927: 8: 626-35.

15. Wilson SJ, Hulsey S, Weidman FD. Chromoblastomycosis in Texas. Arch Dermatol Syphilol. 1933: 27:107-22.

16. Moore M, Almeida F de. Etiologic agents of chromycosis (Chromoblastomycosis of Terra. Torres, Fonseca and Leão, 1922) of North and South America. Rev Biol Hyg. 1935; 6:94-7.

17. Rippon JW. Chromoblastomycosis and related dermal infections caused by dematiaceous fungi. Medical Mycology.The Pathogenic Fungi and the Pathogenic Actinomycetes. 2nd ed. Philadelphia, Pa: WB Saunders; 1982. p.249-76.

18. Borelli D. Acrotheca aquaspersa: nova species agente de Cromomicosis. Acta Cient Venez. 1972;23:193-6.

19. De Hoog GS, Queiroz-Telles F, Haase G, Fernandez-Zeppenfeldt G, Attili Angelis D, Gerrits Van Den Ende AH, et al. Black fungi: clinical and pathogenic approaches. Med Mycol. 2000;38 Suppl 1:243-50.

20. Kwon-Chung KJ, Bennett J. Chromoblastomycosis, In: Kwon-Chung KJ, Bennett J. Medical Mycoloy. Philadelphia: Lea \& Febiger, 1992. p.337-55.

21. Najafzadeh MJ, Sun J, Vicente V, Xi L, van den Ende AH, de Hoog GS. Fonsecaea nubica sp. nov, a new agent of human chromoblastomycosis revealed using molecular data. Med Mycol. 2010;48:800-6.

22. de Azevedo CM, Gomes RR, Vicente VA, Santos DW, Marques SG, do Nascimento MM, et al. Fonsecaea pugnacius, a Novel Agent of Disseminated Chromoblastomycosis. J Clin Microbiol. 2015;53:2674-85.

23. Queiroz-Telles F, Esterre P, Perez-Blanco M, Vitale RG, Salgado CG, Bonifaz A. Chromoblastomycosis: an overview of clinical manifestations, diagnosis and treatment. Med Mycol. 2009:47:3-15.

24. Gomes RR, Vicente VA, Azevedo CM, Salgado CG, da Silva MB, Queiroz-Telles F, et al. Molecular epidemiology of agents of human Chromoblastomycosis in Brazil with the description of two novel specieis. PLoS Negl Trop Dis. 2016;10:e0005102.

25. Heidrich D, González GM, Pagani DM, Ramírez-Castrillón M, Scroferneker ML. Chromoblastomycosis caused by Rhinocladiella similis: Case report. Med Mycol Case Rep. 2017:16:25-27.

26. De Hoog GS, Attili-Angelis D, Vicente VA, Van Den Ende AH, Queiroz-Telles F. Molecular ecology and pathogenic potential of Fonsecaea species. Med Mycol. 2004 0ct:42:405-16.

27. Pérez-Blanco $M$, Hernández Valles $R$, García-Humbría $L$, Yegres $F$. Chromoblastomycosis in children and adolescents in the endemic area of the Falcon State, Venezuela. Med Mycol. 2006;44:467-71.

28. Queiroz-Telles F, Nucci M, Colombo AL, Tobón A, Restrepo A. Mycoses of implantation in Latin America: an overview of epidemiology, clinical manifestations, diagnosis and treatment. Med Mycol. 2011;49:225-36.

29. Bonifaz A, Carrasco-Gerard E, Saúl A. Chromoblastomycosis: clinical and mycologic experience of 51 cases. Mycoses. 2001;44(1-2):1-7.
30. Silva JP, de Souza W, Rozental S. Chromoblastomycosis: a retrospective study of 325 cases on Amazonic Region (Brazil). Mycopathologia. 1998-1999;143:171-5.

31. Naka W, Harada T, Nishikawa T, Fukushiro R. A case of chromoblastomycosis: with special reference to the mycology of the isolated Exophiala jeanselmei. Mykosen. 1986;29:445-52.

32. Barba-Gómez JF, Mayorga J, McGinnis MR, González-Mendoza A Chromoblastomycosis caused by Exophiala spinifera. J Am Acad Dermatol. 1992;26:367-70.

33. Padhye AA, Hampton AA, Hampton MT, Hutton NW, Prevost-Smith E, Davis MS. Chromoblastomycosis caused by Exophiala spinifera. Clin Infect Dis. 1996;22:331-5

34. Tomson N, Abdullah A, Maheshwari MB. Chromomycosis caused by Exophiala spinifera. Clin Exp Dermatol. 2006;31:239-41.

35. Piepenbring M, Cáceres Mendez OA, Espino Espinoza AA, Kirschner R, Schöfer H. Chromoblastomycosis caused by Chaetomium funicola: a case report from Western Panama. Br J Dermatol. 2007;157:1025-9.

36. Matsumoto T, Matsuda T, McGinnis MR, Ajello L. Clinical and mycological spectra of Wangiella dermatitidis infections. Mycoses. 1993;36:145-55.

37. Schnitzler N, Peltroche-Llacsahuanga H, Bestier N, Zündorf J, Lütticken R, Haase G. Effect of melanin and carotenoids of Exophiala (Wangiella) dermatitidis on phagocytosis, oxidative burst, and killing by human neutrophils. Infect Immun. 1999;67:94-101.

38. Brygoo ER, Destombes P. Epidemiologie de la chromoblastomycose humaine. Bull Inst Pasteur. 1975;74:219-43.

39. Esterre P, Andriantsimahavandy A, Raharisolo C. Natural history of chromoblastomycosis in Madagascar and the Indian Ocean. Bull Soc Pathol Exot. 1997;90(5):312-7.

40. Berger L, Langeron M. Sur un type noveau de chromomycose observé au Canada (Torulabergeri n. sp). Ann Parasitol Hum Comp. 1949;24:574-99

41. Putkonen T. Chromomycosis in Finland. The possible role of the Finnish sauna in its spreading. Hautarzt. 1966;17:507-9

42. Sonck CE. Chromomycosis in Finland. Dermatology. 1975; 19:189-93.

43. Pindycka-Piaszczyńska M, Krzyściak P, Piaszczyński M, Cieślik S, Januszewski $\mathrm{K}$, Izdebska-Straszak G,et al. Chromoblastomycosis as an endemic disease in temperate Europe: first confirmed case and review of the literature. Eur J Clin Microbiol Infect Dis. 2014;33:391-8.

44. Nishimoto K. Chromomycosis in Japan. Ann Soc Belg Med Trop. 1981:61:405-12

45. Fukushiro R. Chromomycosis in Japan. Int J Dermatol. 1983;22:221-9.

46. Campins H, Scharyj M. Chromoblastomicosis: comentarios sobre 34 casos con estudio clínico, histológico y micológico. Gac Med (Caracas). 1953; 61:127-51

47. Minotto R, Bernardi CD, Mallmann LF, Edelweiss Ml, Scroferneker ML. Chromoblastomycosis: a review of 100 cases in the state of Rio Grande do Sul, Brazil. J Am Acad Dermatol. 2001:44:585-92.

48. Lacaz CS, Porto E, Martins JEC. Fungos, actinomicetos e algas de interesse médico. Micologia Médica. 8th ed. São Paulo: Sarvier; 1991. p.373-86.

49. Conant NF. The occurrence of a human pathogenic fungus as a saprophyte in nature. Mycologia. 1937; 29:597-8.

50. Silva ACCM, Serra Neto A, Galvão CES, Marques SG, Saldanha ACR, Silva CMP, et al. Cromoblastomicose produzida por Fonsecaea pedrosoi no estado do Maranhão. I. Aspectos clínicos, epidemiológicos e evolutivos. Rev Soc Bras Med Trop. 1992;25:37- 44.

51. Londero AT, Ramos CD. Chromomycosis: a clinical and mycologic study of thirtyfive cases observed in the hinterland of Rio Grande do Sul, Brazil. Am J Trop Med Hyg. 1976;25:132-5.

52. Silva CM, da Rocha RM, Moreno JS, Branco MR, Silva RR, Marques SG, et al. The coconut babaçu (Orbignyaphalerata martins) as a probable risk of human infection by the agent of chromoblastomycosis in the State of Maranhão, Brazil. Rev Soc Bras Med Trop. 1995;28:49-52.

53. Salgado CG, da Silva JP, Diniz JA, da Silva MB, da Costa PF, Teixeira C, et al. Isolation of Fonsecaea pedrosoi from thorns of Mimosa pudica, a probable natura source of chromoblastomycosis. Rev Inst Med Trop Sao Paulo. 2004:46:33-6.

54. Zeppenfeldt G, Richard-Yegres N, Yegres F. Cladosporium carrionii: hongo dimórfico en cactáceas de la zona endémica para la cromomicosis en Venezuela. Rev Iberoam Micol. 1994;11:61-3.

55. d'Avila SC, Pagliari C, Duarte MI. The cell-mediated immune reaction in the cutaneous lesion of chromoblastomycosis and their correlation with different clinical forms of the disease. Mycopathologia. 2003;156:51-60.

56. Sousa MG, de Maria Pedrozo e Silva Azevedo C, Nascimento RC, Ghosn EE, Santiago KL, Noal V, et al. Fonsecaea pedrosoi infection induces differential modulation of costimulatory molecules and cytokines in monocytes from patients with severe and mild forms of chromoblastomycosis. J Leukoc Biol. 2008;84:864-70. 
57. Nimrichter L, Barreto-Bergter E, Mendonça-Filho RR, Kneipp LF, Mazzi MT, Salve P, et al. A monoclonal antibody to glucosylceramide inhibits the growth of Fonsecaea pedrosoi and enhances the antifungal action of mouse macrophages. Microbes Infect. 2004;6:657-65.

58. Hayakawa M, Ghosn EE, da Gloria Teixeria de Sousa M, Ferreira KS, Almeida SR. Phagocytosis, production of nitric oxide and pro-inflammatory cytokines by macrophages in the presence of dematiaceous fungi that cause chromoblastomycosis. Scand J Immunol. 2006;64:382-7.

59. Bocca AL, Brito PP, Figueiredo F, Tosta CE. Inhibition of nitric oxide production by macrophages in chromoblastomycosis: a role for Fonsecaea pedrosoi melanin. Mycopathologia. 2006:161:195-203.

60. Sotto MN, De Brito T, Silva AM, Vidal M, Castro LG. Antigen distribution and antigen-presenting cells in skin biopsies of human chromoblastomycosis. J Cutan Pathol. 2004;31:14-8.

61. Mazo Fávero Gimenes V, Da Glória de Souza M, Ferreira KS, Marques SG, Gonçalves AG, Vagner de Castro Lima Santos D, et al. Cytokines and lymphocyte proliferation in patients with different clinical forms of chromoblastomycosis Microbes Infect. 2005;7:708-13.

62. da Silva JP, da Silva MB, Salgado UI, Diniz JA, Rozental S, Salgado CG. Phagocytosis of Fonsecaea pedrosoi conidia, but not sclerotic cells caused by Langerhans cells, inhibits CD40 and B7-2 expression. FEMS Immunol Med Microbiol. 2007;50:104-11

63. Silva AA, Criado PR, Nunes RS, da Silva WL, Kanashiro-Galo L, Duarte MI, et al. In Situ Immune Response in Human Chromoblastomycosis - A Possible Role for Regulatory and Th17 T Cells. PLoS Negl Trop Dis. 2014;8:e3162.

64. Siqueira IM, de Castro RJA, Leonhardt LCM, Jerônimo MS, Soares AC, Raiol T et al. Modulation of the immune response by Fonsecaea pedrosoi morphotypes in the course of experimental chromoblastomycosis and their role on inflammatory response chronicity. PLoS Negl Trop Dis. 2017:11:e0005461.

65. Carrión AL. Chromoblastomycosis. Ann N Y Acad Sci. 1950;50:1255-82.

66. Salgado CG, da Silva MB, Yamano SS, Salgado UI, Diniz JA, da Silva JP. Cutaneous localized annular chromoblastomycosis. J Cutan Pathol. 2009;36:257-61.

67. Salgado CG, da Silva JP, da Silva MB, da Costa PF, Salgado UI. Cutaneous diffuse chromoblastomycosis. Lancet Infect Dis. 2005;5:528.

68. Krishna S, Shenoy MM, Pinto M, Saxena V. Two cases of axillary chromoblastomycosis. Indian J Dermatol Venereol Leprol. 2016;82:455-6.

69. El Euch D, Mokni M, Haouet S, Trojjet S, Zitouna M, Ben Osman A.. Erythematosquamous papular and atrophic plaque on abdomen: chromoblastomycosis due to Fonsecaeapedrosoi. Med Trop (Mars). 2010;70:81-3.

70. Barton K, Miller D, Pflugfelder SC. Corneal chromoblastomycosis. Cornea. 1997:16:235-9

71. Bui AQ, Espana EM, Margo CE. Chromoblastomycosis of the conjunctiva mimicking melanoma of the ciliary body. Arch Ophthalmol. 2012;130:1615-7.

72. Bittencourt AL, Londero AT, Andrade JAF. Cromoblastomicose auricular: relato de um caso. Rev Inst Med trop São Paulo. 1994:36:381-3.

73. França K, Villa RT, Bastos VR, Almeida AC, Massucatti K, Fukumaru D, et al. Auricular Chromoblastomycosis: A Case Report and Review of Published Literature. Mycopathologia. 2011;172:69-72.

74. Arango M, Jaramillo C, Cortés A, Restrepo A. Auricular chromoblastomycosis caused by Rhinocladiella aquaspersa. Med Mycol. 1998;36:43-5

75. Muñoz Estrada VF, Valenzuela Paz GA, Rochín Tolosa M. Cromomicosis: Reporte de un caso contopografía atípica. Rev Iberoam Micol. 2011;28:50-2.

76. Naveen KN, Shetty PC, Naik AS, Pai VV, Hanumanthayya K, Udupishastry D. Chromoblastomycosis presenting as a phagedenic ulcer on the face. Int $J$ Dermatol. 2012;51:576-8.

77. Fatemi MJ, Bateni H. Oral chromoblastomycosis: a case report. Iran J Microbiol. 2012;4:40-3

78. Takase T, Baba T, Uyeno K. Chromomycosis. A case with a widespread rash, lymph node metastasis and multiple subcutaneous nodules. Mycoses. 1988;31:343-52.

79. Camara-Lemarroy CR, Soto-Garcia AJ, Preciado-Yepez Cl, Moreno-Hoyos Hernandez-Rodriguez PA, Galarza-Delgado DA. Case of chromoblastomycosis with pulmonary involvement. J Dermatol. 2013:40:746-8.

80. Sharma NL, Sharma VC, Mahajan V, Shanker V, Sarin S. Chromoblastomycosis with underlying osteolytic lesion. Mycoses. 2007;50:517-9.

81. Queiroz-Telles F, McGinnis MR, Salkin I, Graybill JR. Subcutaneous mycoses. Infect Dis Clin North Am. 2003;17:59-85.

82. Sharma N. Marfatia YS. Genital elephantiasis as a complication of chromoblastomycosis: A diagnosis overlooked. Indian J Sex Transm Dis. 2009;30:43-5.

83. Caplan RM. Epidermoid carcinoma arising in extensive chromoblastomycosis Arch Dermatol. 1968:97:38-41.

84. Foster HM, Harris TJ. Malignant change (squamous carcinoma) in chronic chromoblastomycosis. Aust N Z J Surg. 1987:57:775-7.
85. Esterre P, Pecarrère JL, Raharisolo C, Huerre M. Squamous cell carcinoma arising from chromomycosis. Report of two cases. Ann Pathol. 1999;19:516-20.

86. dos Santos Gon A, Minelli L. Melanoma in a long-standing lesion of chromoblastomycosis. Int J Dermatol. 2006;45:1331-3.

87. Torres E, Beristain JG, Lievanos Z, Arenas R. Chromoblastomycosis associated with a lethal squamous cell carcinoma. An Bras Dermatol. 2010;85:267-70.

88. Jamil A, Lee YY, Thevarajah S. Invasive squamous cell carcinoma arising from chromoblastomycosis. Med Mycol. 2012;50:99-102.

89. Azevedo CM, Marques SG, Santos DW, Silva RR, Silva NF, Santos DA, et al. Squamous cell carcinoma derived from chronic chromoblastomycosis in Brazil. Clin Infect Dis. 2015:60:1500-4

90. Rojas OC, González GM, Moreno-Treviño M, Salas-Alanis J. Chromoblastomycosis by Cladophialophora carrionii associated with squamous cell carcinoma and review of published reports. Mycopathologia. 2015;179:153-7.

91. Miranda MF, Silva AJ. Vinyl adhesive tape also effective for direct microscopy diagnosis of chromomycosis, lobomycosis, and paracoccidioidomycosis. Diagn Microbiol Infect Dis. 2005;;52:39-43.

92. de Andrade TS, Cury AE, de Castro LG. Hirata MH, Hirata RD. Rapid identification of Fonsecaea by duplex polymerase chain reaction in isolates from patients with chromoblastomycosis. Diagn Microbiol Infect Dis. 2007:57:267-72.

93. Oberto-Perdigón L, Romero H, Pérez-Blanco M, Apitz-Castro R. An ELISA test for the study of the therapeutic evolution of chromoblastomycosis by Cladophialophora carrionii in the endemic area of Falcon State, Venezuela. Rev Iberoam Micol. 2005;22:39-43.

94. Lee MW, Hsu S, Rosen T. Spores and mycelia in cutaneous chromomycosis. J Am Acad Dermatol. 1998:39:850-2.

95. Avelar-Pires C, Simoes-Quaresma JA, Moraes-de Macedo GM, Brasil-Xavier M, Cardoso-de Brito A. Revisiting the clinical and histopathological aspects of patients with chromoblastomycosis from the Brazilian Amazon region. Arch Med Res. 2013;44:302-6.

96. Lokuhetty MD, Alahakoon VS, Kularatne BD, De Silva MV. ZeilNeelson and WadeFite stains to demonstrate medlar bodies of chromoblastomycosis. J Cutan Pathol. 2007;34:71-2.

97. Saxena AK, Jain S, Ramesh V, Singh A, Capoor MR. Chromoblastomycosis: demonstration of abundant microorganisms on microscopy of a scaly crust following intralesional corticosteroids. J Eur Acad Dermatol Venereol. 2015;29:189-90.

98. Bonifaz A, Paredes-Solís V, Saúl A. Treating chromoblastomycosis with systemic antifungals. Expert Opin Pharmacother. 2004;5:247-54.

99. Bonifaz A, Martínez-Soto E, Carrasco-Gerard E, Peniche J. Treatment of chromoblastomycosis with itraconazole, cryosurgery and a combination of both. Int J Dermatol. 1997:36:542-7.

100. Castro LG, Pimentel ER, Lacaz CS. Treatment of chromomycosis by cryosurgery with liquid nitrogen: 15 years'experience. Int J Dermatol. 2003;42:408-12.

101. Tagami H, Ginoza M, Imaizumi S, Urano-Suehisa S. Successful treatment of chromoblastomycosis with topical heat therapy. J Am Acad Dermatol. 1984;10:615-9

102. Hiruma M, Kawada A, Yoshida M, Kouya M. Hyperthermic treatment of chromomycosis with disposable chemicalpocket warmers. Report of a successfully treated case, with a review of the literature. Mycopathologia. 1993;122:107-14.

103. Tsianakas A, Pappai D, Basoglu Y, Metze D, Tietz HJ, Luger TA, et al. Chromomycosis: successful CO2 laser vaporization. J Eur Acad Dermatol Venereol. 2008:22:1385-6.

104. Hira K, Yamada H, Takahashi Y, Ogawa H.Successful treatment of chromomycosis using carbon dioxide laser associated with topical heat applications. J Eur Acad Dermatol Venereol. 2002;16:273-5

105. Lyon JP, Pedroso e Silva Azevedo Cde M, Moreira LM, de Lima CJ, de Resende MA Photodynamic antifungal therapy against chromoblastomycosis. Mycopathologia. 2011:172:293-7.

106. Yang $\mathrm{Y}$, Hu $\mathrm{Y}$, Zhang J, Li X, Lu C, Liang $\mathrm{Y}$, et al. A refractory case of chromoblastomycosis due to Fonsecaea monophora with improvement by photodynamic therapy. Med Mycol. 2012;50:649-53.

107. Hu Y, Huang X, Lu S, Hamblin MR, Mylonakis E, Zhang J, et al. Photodynamic therapy combined with terbinafine against chromoblastomycosis and the effect of PDT on Fonsecaea monophora in vitro. Mycopathologia. 2015;179:103-9.

108. Pavlidakey GP, Snow SN, Mohs FE. Chromoblastomycosis treated by Mohs micrographic surgery. J Dermatol Surg Oncol. 1986;12:1073-5

109. Bonifaz A, Carrasco-Gerard E, Saúl A. Chromoblastomycosis; clinical and mycologic experience of 51 cases. Mycoses. 2001;44:1-7.

110. Esterre P, Inzan CK, Ramarcel ER, Andriantsimahavandy A, Ratsioharana M, Pecarrere $\mathrm{JL}$, et al. Treatment of chromomycosis with terbinafine: preliminary results of an open pilot study. Br J Dermatol. 1996:134:33-6. 
111. Queiroz-Telles F, McGinnis MR, Salkin I, Graybill JR. Subcutaneous mycoses. Infect Dis Clin North Am. 2003;17:59-85.

112. Bonifaz A, Saúl A, Paredes-Solis V, Araiza J, Fierro-Arias L. Treatment of chromoblastomycosis with terbinafine: experience with four cases. J Dermatolog Treat. 2005:16:47-51.

113. Xibao Z, Changxing L, Quan L, Yuqing H.. Treatment of chromoblastomycosis with terbinafine: a report of four cases. J Dermatolog Treat. 2005;16:121-4.

114. McGinnis MR, Pasarell L. In vitro evaluation of terbinafine and itraconazole against dematiaceous fungi. Med Mycol. 1998;36:243-6.

115. Caligiorne RB, Resende MA, Melillo PH, Peluso CP, Carmo FH, Azevedo V. In vitro susceptibility of chromoblastomycosis and phaeohyphomycosis agents to antifungal drugs. Med Mycol. 1999;37:405-9.

116. Kumarasinghe SP, Kumarasinghe MP. Itraconazole pulse therapy in chromoblastomycosis. Eur J Dermatol. 2000;10:220-2.

117. Ungpakorn R, Reangchainam S. Pulse itraconazole $400 \mathrm{mg}$ daily in the treatment of chromoblastomycosis. Clin Exp Dermatol. 2006;31:245-7.

118. Gupta AK, Taborda PR, Sanzovo AD. Alternate week and combination itraconazole and terbinafine therapy for chromoblastomycosis caused by Fonsecaea pedrosoi in Brazil. Med Mycol. 2002;40:529-34.

119. KooS, Klompas M, Marty FM. Fonsecaea monophora cerebral phaeohyphomycosis: case report of successful surgical excision and voriconazole treatment and review. Med Mycol. 2010;48:769-74.

120. Lima AM, Sacht GL, Paula LZ, Aseka GK, Goetz HS, Gheller MF, et al. Response of chromoblastomycosis to voriconazole. An Bras Dermatol. 2016;91:679-681.

121. Criado PR, Careta MF, Valente NY, Martins JE, Rivitti EA, Spina R, et al. Extensive long-standing chromomycosis due to Fonsecaea pedrosoi: three cases with relevant improvement under voriconazole therapy. J Dermatolog Treat. 2011;22:167-74

122. Negroni R, Tobón A, Bustamante B, Shikanai-Yasuda MA, Patino H, Restrepo A. Posaconazole treatment of refractory eumycetoma and chromoblastomycosis. Rev Inst Med Trop Sao Paulo. 2005:47:339-46.

123. Lopes CF, Alvarenga RJ, Cisalpino EO, Resende MA, Oliveira LG. Six years experience in treatment of chromomycosis with 5-fluorocytosine. Int J Dermatol. 1978;17:414-8.
124. Park SG, Oh SH, Suh SB, Lee KH, Chung KY. A case of chromoblastomycosis with an unusual clinical manifestation caused by Phialophora verrucosa on an unexposed area: treatment with a combination of amphotericin B and 5-flucytosine. Br J Dermatol. 2005;152:560-4.

125. Bolzinger T, Pradinaud R, Sainte-Marie D, Dupont B, Chwetzoff E. Traitement de quatrecas de chromomycose à Fonsecaea pedrosoi par l'association 5-fluorocytosine-itraconazole. Nouv Dermatol. 1991;10:462- 6.

126. Antonello VS, Appel da Silva MC, Cambruzzi E, Kliemann DA, Santos BR, Queiroz-Telles F. Treatment of severe chromoblastomycosis with itraconazole and 5-flucytosine association. Rev Inst Med Trop Sao Paulo. 2010;52:329-31.

127. Kubala L, Ruzickova J, Nickova K, Sandula J, Ciz M, Lojek A. The effect of (1-3)- $\beta$-d-glucans, carboxymethylglucan and schizophyllan on human leukocytes in vitro. Carbohydr Res. 2003;338:2835-40.

128. Meira DA, Pereira PC, Marcondes-Machado J, Mendes RP, Barraviera B, Pellegrino Júnior $\mathrm{J}$, et al. The use of glucan as immunostimulant in the treatment of paracoccidioidomycosis. Am J Trop Med Hyg. 1996;55:496-503.

129. Azevedo Cde M, Marques SG, Resende MA, Gonçalves AG, Santos DV, da Silva $R R$, et al. The use of glucan as immunostimulant in the treatment of a severe case of chromoblastomycosis. Mycoses. 2008;51:341-4.

130. Azevedo CMPS, Leda YA, Oliveira TKM, Barbosa A, Branco DAC. P0247 Efeito da glucana em um caso de cromoblastomicose refratário a antifúngico. In: Pôsters apresentados no 60 o Congresso da Sociedade Brasileira de Dermatologia. Departamento de Micologia; 2005 set 10 a 14. An Bras Dermatol. 2005: 80:S226-S32.

131. Buates S, Matlashewski G. Treatment of experimental leishmaniasis with the immunomodulators imiquimod and S-28463: efficacy and mode of action. J Infect Dis. 1999;179:1485-94.

132. Sousa Mda G, Reid DM, Schweighoffer E, Tybulewicz V, Ruland J, Langhorne $J$,et al. Restoration of pattern recognition receptor costimulation to treat chromoblastomycosis, a chronic fungal infection of the skin. Cell Host Microbe. 2011:9:436-43.

133. de Sousa Mda G, Belda W Jr, Spina R, Lota PR, Valente NS, Brown GD, et al. Topical application of imiquimod as a treatment for Chromoblastomycosis. Clin Infect Dis. 2014:58:1734-7.

\section{AUTHORS CONTRIBUTION}

Arival Cardoso de Brito

Approval of the final version of the manuscript; Conception and planning if the study; Elaboration and writing of the manuscript; Obtaining, analyzing and interpreting the data; Effective participation in research orientation; Intellectual participation in propaedeutic and/or therapeutic conduct of cases studied; Critical review of the literature; Critical review of the manuscript

Malaya de Jesus Sembilan Bittencourt iD ORCID 0000-0002-7297-0749

Conception and planning of the study; Elaboration and writing of the manuscript; $\mathrm{Ob}$ taining, analyzing and interpreting the data; Effective participation in research orientation; Intellectual participation in propaedeutic and/or therapeutic conduct of cases studied; Critical review of the literature

How to cite this article: Brito AC, Bittencourt MJS. Chromoblastomycosis: an etiological, epidemiological, clinical, diagnostic, and treatment update. An Bras Dermatol. 2018;93(4):495-506. 


\section{QUESTÕES}

1. The following are causative species of CBM, except:
a) Fonsecaea pedrosoi
b) Cladophialophora carrionii
c) Rhinocladiella aquaspersa
d) Penicillium marneffei

2. Melanin (dihydroxy naphthalene-melanin) in the wall of etiological agents of CBM is considered:
a) A factor for resistance to antifungal agents
b) A factor for virulence pathogenicity
c) Only defines the color
d) A reproductive factor

3. The following are considered clinical forms of CMB, except:
a) nodular
b) verrucous
c) macular
d) tumoral

4. As for antifungals used in the treatment of chromomycosis is CORRECT to afirm:

a) Itraconazole and terbinafine show low in vitro activity against the etiological agents of CBM.

b) Second-generation triazoles (voriconazole, ravuconazole, posaconazole) do not display in vitro activity against dematiaceous fungi.

c) Ketoconazole is still recommended as an option for prolonged treatment.

d) Fluconazole is not recommended, since in vitro studies showed little activity against dematiaceous fungi.

5. Concerning the use of amphotericin for the treatment of CBM, mark the CORRECT answer:
a) Quite effective as monotherapy
b) Safe drug for severe forms of the disease
c) The combination with fluorocytosine has shown effi- cacy in in vitro studies
d) The drug of choice for localized lesions

6. Cladosporium type fruiting is characterized by:
a) Flower vase-shaped conidiophore (phialide) with spores around the phialide
b) Conidiophores formed along the hyphae and oval spores on the upper extremity (acrotheca)
c) Acrogenous catenulate sporulation, elliptical spores in chains.
d) Brush-shaped conidiophore

7. As for the immunology of chromobastomycosis, mark the CORRECT answer:

a) Verrucous lesions show a predominance of IL4 and IL10

b) Humoral immune response predominates

c) Th2 profile predominates in atrophic lesions

d) Low expression of IL-17 in the lesions

8. The black dots in CMB lesions represent:

a) Thrombosed vessels on the lesion's surface

b) Hematic crusts

c) Transdermal elimination of the fungus

d) Melanocyte proliferation

9. As for classification of CBM lesions according to Queiroz-Telles, the mild form is characterized by:

a) Single lesion, plaque or nodular type, less than $5 \mathrm{~cm}$ in diameter

b) Single lesion, plaque or nodular type, less than $10 \mathrm{~cm}$ in diameter.

c) Single verrucous lesion less than $5 \mathrm{~cm}$ in diameter.

d) Multiple lesions, plaque or nodular type, less than $5 \mathrm{~cm}$ in diameter.

10. The etiological agents of CBM belong to the family:
a) Ajellomycetaceae
b) Botryobasidiacea
c) Herpotrichiellaceae
d) Hydnaceae

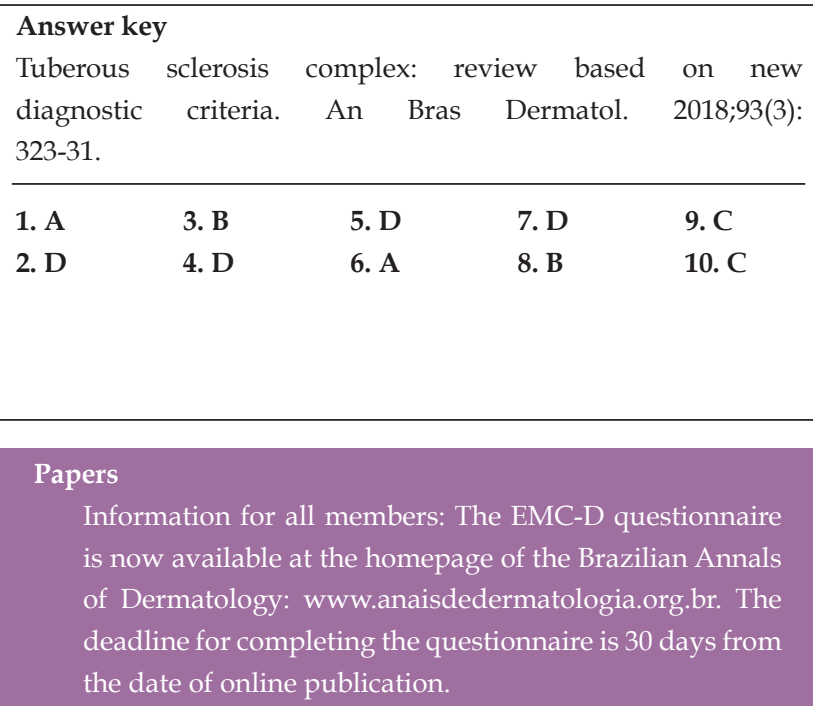

